Int. J. Dev. Biol. 63: 301-309 (2019)

https://doi.org/10.1387/ijdb.190006ed

\title{
Transcriptome analysis of regeneration during Xenopus laevis experimental twinning
}

\author{
ERIC A. SOSA ${ }^{\#, 1}$, YUKI MORIYAMA ${ }^{\#, 2}$, YI DING ${ }^{1}$, NYDIA TEJEDA-MUÑOZ ${ }^{1}$, GABRIELE COLOZZA \\ and EDWARD M. DE ROBERTIS*,1 \\ ${ }^{1}$ Howard Hughes Medical Institute, Department of Biological Chemistry, David Geffen School of Medicine, University \\ of California, Los Angeles, CA, USA and ${ }^{2}$ Chuo University, Faculty of Science and Engineering, Tokyo, Japan
}

\begin{abstract}
Animal embryos have the remarkable property of self-organization. Over 125 years ago, Hans Driesch separated the two blastomeres of sea urchin embryos and obtained twins, in what was the foundation of experimental embryology. Since then, embryonic twinning has been obtained experimentally in many animals. In a recent study, we developed bisection methods that generate identical twins reliably from Xenopus blastula embryos. In the present study, we have investigated the transcriptome of regenerating half-embryos after sagittal and dorsal-ventral (D-V) bisections. Individual embryos were operated at midblastula (stage 8) with an eyelash hair and cultured until early gastrula (stage 10.5) or late gastrula (stage 12) and the transcriptome of both halves were analyzed by RNA-seq. Since many genes are activated by wound healing in Xenopus embryos, we resorted to stringent sequence analyses and identified genes up-regulated in identical twins but not in either dorsal or ventral fragments. At early gastrula, cell division-related transcripts such as histones were elevated, whereas at late gastrula, pluripotency genes (such as sox2) and germ layer determination genes (such as eomesodermin, ripply2 and activin receptor ACVRI) were identified. Among the down-regulated transcripts, sizzled, a regulator of Chordin stability, was prominent. These findings are consistent with a model in which cell division is required to heal damage, while maintaining pluripotency to allow formation of the organizer with a displacement of $90^{\circ}$ from its original site. The extensive transcriptomic data presented here provides a valuable resource for data mining of gene expression during early vertebrate development.
\end{abstract}

KEY WORDS: Xenopus laevis, twinning, regeneration, pluripotency, self-organization

Self-organization is a remarkable property of animal embryos. Experimental embryology started when Hans Driesch separated the first two blastomeres of sea urchin embryos and obtained twin larvae (Driesch, 1891). In insects, duplicated embryos can be obtained by partially sectioning the blastoderm (Krause and Sander, 1962). In the chick, when the early blastoderm is sliced into four fragments multiple embryos are formed (Spratt and Haas, 1960), and removal of the hypoblast or inhibition of Nodal signaling also leads to the formation of multiple primitive streaks (Bertocchini and Stern, 2002). In humans, monozygotic twins are delivered in three of 1,000 live births (Hall, 2003), and the armadillo has obligate polyembryony giving rise to identical quadruplets from each egg (Carter, 2018). Mammalian embryonic stem cells in culture have the ability to self-organize into complex organoids (Sasai, 2013). Recently, gastrula-like aggregates have been obtained by self-assembly of mouse (Sozen et al., 2018) or human (Warmflash et al., 2014; Martyn et al., 2018) embryonic stem cells under appropriate conditions.

In Amphibia, the study of twinning has a long history. When one of the two initial blastomeres of the frog embryo is removed,

Abbreviations used in this paper: ACVR1, activin A receptor type 1; BMP, bone morphogenetic protein; D-V, dorso-ventral; MBS, modified Barth's solution; Pkdcc/ Vlk, protein kinase domain containing, cytoplasmic /vertebrate lonesome kinase; RPKM, reads per kilobase per million mapped reads.

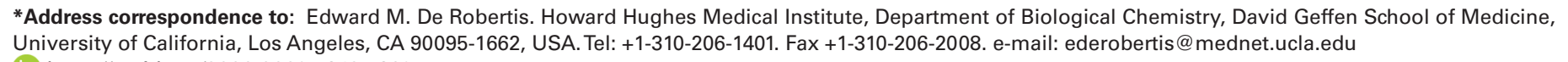
(iD) https://orcid.org/0000-0002-7843-1869

Supplementary Material (two tables) for this paper is available at: https://doi.org/10.1387/ijdb.190006ed \#Note: equal contribution.

Submitted: 8 January, 2019; Accepted: 4 April, 2019.

ISSN: Online 1696-3547, Print 0214-6282

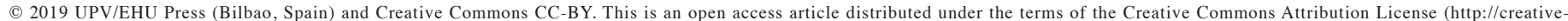

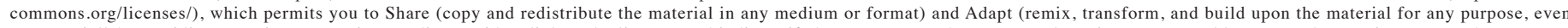

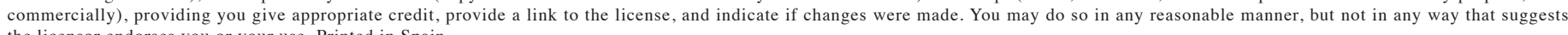
the licensor endorses you or your use. Printed in Spain 
a complete embryo can result (Morgan, 1895). This represents the ultimate feat in regeneration, for the missing half of the body, with all the tissues that this implies, can regenerate from only half an egg. Using partial constriction with a baby hair loop, Spemann obtained two well-proportioned embryos from the same salamander egg (Spemann, 1901). In Xenopus, identical twins can be generated after sagittally cutting the embryo with a scalpel (De Robertis, 2006) but at very low frequencies, precluding meaningful mechanistic studies. However, in a recent study we improved methods for obtaining Xenopus laevis identical twins by using an eyelash knife and improved culture conditions (Moriyama and De Robertis, 2018). Using cell lineage studies we could recently analyze the developmental mechanism of twinning. We found that the large wound caused by sagittal bisection closes rapidly from all directions within an hour, so that tissue that normally would have been the most dorsal becomes directly juxtaposed to ventral-most cells at the healing point. Formation of the future dorsal lip (i.e., the Spemann organizer) was displaced by $90^{\circ}$ from the healing point. The BMP (Bone Morphogenetic Protein) gradient marked by nuclear phospo-Smad1/5/8 was also displaced, but in the opposite direction. In this way, the entire $\mathrm{D}-\mathrm{V}$ morphogenetic gradient is respecified by repositioning signaling centers (Moriyama and De Robertis, 2018).

The recent completion of the Xenopus laevis genome sequence

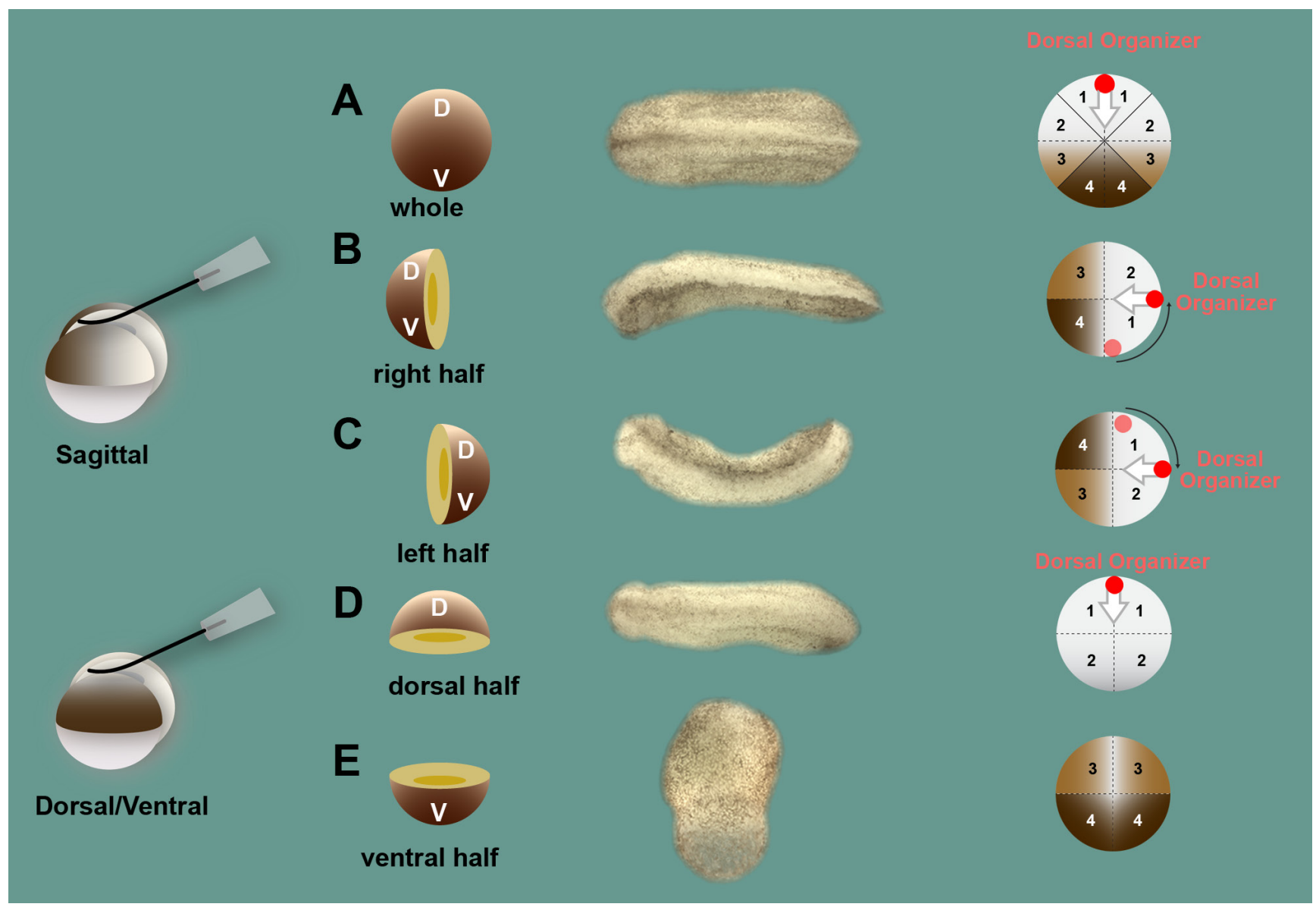

Fig. 1. Diagram of the experimental procedure used to investigate regeneration in Xenopus laevis half embryos. On the left, drawing of blastula embryos being bisected in the sagittal or DorsalNentral directions. Middle, the five samples used to generate RNA-seq libraries. (A) Uncut whole embryo. (B) Right half embryo cut sagittally; note that the maternal pigment is darker on the left side of the tailbud tadpole (while it is uniform in the whole embryo). (C) Left half from the same blastula; note that pigment asymmetry is concentrated on the right side. (D) Dorsal half embryo at tailbud showing almost perfect scaling of the half embryo along the antero-posterior axis. (E) Ventral half embryo; because it lacks the Spemann organizer it develops into a belly-piece consisting of ventral tissues, such as blood and lateral plate, without any dorsal axis (Spemann, 1938). Photographs for right and left half tailbud embryos are reproduced, with permission, from Moriyama and De Robertis, 2018, while dorsal and ventral half embryos are unpublished but from the same experimental batch. On the right-hand side, diagrams showing how the displacement by $90^{\circ}$ of the Spemann organizer explains the pigment asymmetry observed in twinned embryos (Moriyama and De Robertis, 2018). Numbers indicate the four segments into which the 16-cell embryo can be lineage-traced. After bisection the dorsal-most segment 1 becomes juxtaposed (at the wound healing point) to the ventral-most segment 4, which has high BMP and Wnt expression potential. The organizer is not yet formed at midblastula, but at early gastrula the new dorsal lip (organizer indicated by the red dot) forms $90^{\circ}$ away from its original $D$-V location. Embryos in which both halves heal within 60 minutes and in which the organizer forms $90^{\circ}$ away from the healing point have a high percentage (around 80\%) of correct twinning. Segments 4 and 3 form the epidermis, and involution (white arrow) of the displaced organizer splits them into a less pigmented and more pigmented half, thus explaining the intriguing pigmentation asymmetry observed (Moriyama and De Robertis, 2018). Note that in the dorsal half embryo pigmentation is symmetric. Since individual embryos from this five conditions were sequenced $\left(10^{7} 100 \mathrm{bp}\right.$ reads) in triplicate at early and late gastrula, the data for 16,000 gene transcripts presented in the searchable Excel Tables S1 and S2 represents a treasure trove of gene expression at the gastrula stage. 
TABLE 1

TRANSCRIPTS INDUCED BY SAGITTAL BISECTION IN STAGE 10.5 EMBRYOS*

\begin{tabular}{|c|c|c|c|c|c|c|c|c|}
\hline JGI9 ID & Human ID & Con. & L. half & R. half & D. half & V. half & p-value & Exp.\# \\
\hline Xelaev18001465m & HIST2H3A & 4.02 & 22.89 & 17.11 & 7.34 & 1.70 & 0.15 & 1 \\
\hline Xelaev18002543m & HIST2H3A & 6.96 & 18.03 & 17.58 & 13.83 & 4.34 & 0.03 & 2 \\
\hline Xetrov90022513m.1 & HISTH4 & 1.57 & 8.34 & 8.01 & 5.73 & 1.99 & 0.03 & 1 \\
\hline Xelaev18026398m & HISTH4 & 1.69 & 6.44 & 4.46 & 4.22 & 0.83 & 0.17 & 2 \\
\hline krt12.S & KRT12 & 23.40 & 46.94 & 63.96 & 4.45 & 22.45 & 0.42 & 3 \\
\hline krt.L & KRT19 & 1.82 & 25.71 & 17.90 & 0.44 & 3.09 & 0.21 & 3 \\
\hline Xetrov90029514m.1 & HISTH3 & 3.35 & 11.66 & 18.44 & 3.18 & 6.57 & 0.08 & 3 \\
\hline Xetrov90003601m.S & \#N/A & 2.26 & 16.10 & 11.04 & 2.15 & 9.98 & 0.45 & 2 \\
\hline sp7.L & SP7 & 1.41 & 4.80 & 5.30 & 1.34 & 3.40 & 0.07 & 3 \\
\hline
\end{tabular}

*Listed according to average RPKM levels in left and right half-embryos.

by Harland and colleagues opened important experimental possibilities to study embryogenesis in this classical vertebrate model system (Session et al., 2016; Briggs et al., 2018). For example, the gene targets of the late Wnt signal (Kjolby and Harland, 2016) and of the early Wnt signature (Ding et al., 2017a) have been elucidated in detail. Three new Wnt antagonists expressed in the Spemann organizer - Pkdcc/Vlk, Angptl4 and Bighead - were identified in our laboratory using these sensitive techniques (Ding et al., 2017b; Kirsch et al., 2017; Ding et al., 2018).

Hoping to identify regeneration master control genes during twinning, we performed RNA-seq analysis on sagittal bisections of Xenopus embryos. Our initial study (Moriyama and De Robertis, 2018) did not reveal any significant reproducible changes in up-regulated transcripts in triplicate samples, and we speculated this could be due to the possibility that the organizer displacement might not be accompanied by changes in overall gene expression, or to our use of pools of 6 half-embryos per library with some variability in the orientation of the sagittal cut (Moriyama and De Robertis, 2018).

In the present study, we analyzed the transcriptomes of regenerating individual half-embryos. The amount of RNA was sufficient for generating RNA-seq libraries yielding $10^{9}$ base pairs each. Stringent analytical conditions were necessary in order to exclude wound-healing genes that are activated by cutting independently of the orientation of the bisection. Sagittal left and right halves were compared to dorsal and ventral bisections. This allowed us to detect genes that were specifically increased in twinning embryos bisected sagittally at midblastula and cultured until early or late gastrula, but not in D-V half embryos. A few up-regulated genes were identified, which were involved in stem cell and germ layer specification. Among the down-regulated genes sizzled, a regulator of Chordin stability, was identified.

\section{Results}

Fig. 1 illustrates the experimental procedure. Xenopus embryos are a very favorable material for these investigations because the dorsal side can be identified by a less pigmented dorsal crescent from 2-cell onwards due to the rotation of the egg cortex. Regularly cleaving embryos were selected at 4-cell stage (Klein, 1987) and then bisected using an eyelash knife at mid-blastula (stage 8) (Nieuwkoop and Faber, 1967) following the sagittal or D-V axis perpendicular to it (Fig. 1, left) in 0.3 x modified Barth's solution (MBS; Gurdon, 1976). After one hour, embryos were transferred to $0.1 \times$ MBS and cultured until early gastrula stage 10.5 or late gastrula stage 12. When siblings were allowed to develop until tailbud (stage 22), complete regeneration could be seen. Fig. 1 shows images for (A) whole embryos, (B) right half embryos, (C) left half embryos, (D) dorsal half embryos (displaying a very complete scaling of pattern) and (E) ventral half embryos (that lack an organizer and all axial structures). The diagrams on the righthand side of Fig. 1 depict the interpretation of the displacement of Spemann organizer that explains the developmental mechanism of twinning (Moriyama and De Robertis, 2018).

RNA-seq libraries were generated in triplicate for whole control, left sagittal, right sagittal, dorsal and ventral regenerating halfembryos at early and late gastrula. This meant a total of 30 RNA-seq libraries each one generating about $10^{7} 100$-bp single-end reads. All embryos were from the same clutch. These data are presented as RPKM (Reads per Kilobase per Million mapped reads) in Supplementary Table S1 for stage 10.5, and Supplementary Table S2 for stage 12. This information represents a powerful resource for vertebrate embryology, not just for the twinning of sagittal halves but also for $\mathrm{D}-\mathrm{V}$ regulation of gene expression.

Afactor that severely complicates embryonic RNA-seq analyses in Xenopus is the wound-healing response of the embryo. We have described a signature of 743 genes that are up-regulated simply by embryo dissection (Ding et al., 2017b). To circumvent this problem, we took a very stringent approach. Only genes that were increased by more than two-fold with respect to a corresponding uncut embryo were selected (including a difference of 2 RPKM to eliminate genes expressed at low levels). Since injury response genes are similarly activated in both dorsal and ventral fragments, we then chose only genes that were enriched in either the dorsal or ventral fragments. While these multiple selections likely eliminate many relevant genes that are expressed even a fraction more in dorsal and ventral fragments than in sagittal bisections, such an approach gave us the opportunity of detecting transcripts that were activated specifically in regenerating twins, which we had failed to find in previous experiments using pooled half embryos (Moriyama and De Robertis, 2018). Since supplementary Tables S1 and S2 are genome-wide, any transcriptional changes not highlighted here will be represented in this open-source data.

\section{Transcripts up-regulated in twinning embryos}

Table 1 shows the transcripts elevated in sagittal halves at stage 10.5. From the bisection at midblastula to RNA preparation at gastrula about 4.5 hours elapsed, including many injury-response genes. Only 9 genes were scored as elevated in sagittally bisected embryos under the stringent conditions described above. Of these, 
TABLE 2

TRANSCRIPTS INDUCED BY SAGITTAL BISECTION IN STAGE 12 EMBRYOS*

\begin{tabular}{|c|c|c|c|c|c|c|c|c|}
\hline JGI9 ID & Human ID & Con. & L. half & R. half & D. half & V. half & p-value & Exp. \# \\
\hline Xelaev18001880m & sox2 & 12.52 & 31.11 & 32.93 & 28.52 & 1.64 & 0.45 & 1 \\
\hline eomes.S & EOMES & 9.88 & 24.37 & 23.90 & 23.39 & 3.28 & 0.05 & 1 \\
\hline apoc1-like.L & APOC1 & 5.57 & 13.08 & 24.48 & 11.28 & 3.85 & 0.04 & 1 \\
\hline fkbp9.L & FKBP9 & 8.49 & 18.13 & 17.49 & 14.63 & 7.27 & 0.01 & 1 \\
\hline Xelaev18016415m & SERPINH1 & 1.35 & 15.08 & 10.96 & 8.23 & 2.89 & 0.10 & 3 \\
\hline$=$ Xelaev18016415m & SERPINH1 & 2.39 & 13.25 & 11.15 & 5.06 & 0.85 & 0.10 & 1 \\
\hline t) LOC100487498.L & RIPPLY2 & 3.67 & 7.96 & 13.33 & 4.72 & 0.23 & 0.37 & 1 \\
\hline LOC100487498.S & RIPPLY2 & 3.73 & 9.63 & 10.52 & 6.04 & 0.62 & 0.37 & 1 \\
\hline Xelaev18029489m & ZNF451 & 3.13 & 9.09 & 9.95 & 7.72 & 3.68 & 0.31 & 1 \\
\hline Xelaev18003368m & $\# \mathrm{~N} / \mathrm{A}$ & 3.03 & 6.42 & 6.32 & 6.15 & 1.68 & 0.03 & 1 \\
\hline acvr1.L & ACVR1 & 2.93 & 6.13 & 5.89 & 5.69 & 2.31 & 0.04 & 1 \\
\hline Xelaev18036787m & CISD1 & 0.72 & 4.18 & 6.31 & 3.10 & 2.89 & 0.11 & 3 \\
\hline LOC108701590 & FAM220A & 0.00 & 4.22 & 4.46 & 3.64 & 0.83 & 0.25 & 3 \\
\hline Xetrov $90002007 \mathrm{~m} .1$ & NR2C2AP & 0.00 & 3.11 & 4.09 & 2.24 & 0.00 & 0.32 & 1 \\
\hline Xetrov90029514m.1 & HISTH3 & 7.14 & 23.94 & 16.74 & 2.69 & 9.87 & 0.02 & 3 \\
\hline fucolectin-5-like & $\# \mathrm{~N} / \mathrm{A}$ & 5.16 & 16.37 & 23.89 & 1.31 & 4.29 & 0.11 & 1 \\
\hline fucolectin.L & \#N/A & 2.15 & 20.47 & 16.81 & 1.23 & 6.25 & 0.06 & 1 \\
\hline comt.L & \#N/A & 2.61 & 15.69 & 17.65 & 2.61 & 8.68 & 0.28 & 3 \\
\hline (]) Xelaev18025569m & EP300 & 6.06 & 14.23 & 15.42 & 4.60 & 11.73 & 0.27 & 1 \\
\hline Xelaev18002343m & HIST2H2AB & 2.60 & 10.12 & 8.57 & 3.27 & 7.50 & 0.48 & 3 \\
\hline 巴 Xelaev18039781m & SGPP1 & 4.17 & 8.81 & 8.68 & 1.90 & 8.30 & 0.42 & 1 \\
\hline LOC101731107.L & MIEN1 & 1.38 & 10.03 & 6.79 & 0.86 & 6.34 & 0.32 & 3 \\
\hline Xelaev18037854m & GPR161 & 2.95 & 6.24 & 6.40 & 1.40 & 6.13 & 0.11 & 1 \\
\hline Xelaev18037313m & ST3GAL4 & 1.42 & 4.82 & 5.27 & 0.29 & 2.44 & 0.09 & 1 \\
\hline tpx2.S & TPX2 & 0.58 & 3.83 & 5.04 & 1.10 & 3.36 & 0.39 & 3 \\
\hline
\end{tabular}

*Listed according to average RPKM levels in left and right regenerating half-embryos.

5 were histones, which were reproducible between individual embryos analyzed in the 3 experiments; a possible explanation is an increase in cell division or chromatin reorganization during twinning. In addition, two epidermal keratins, KRT12 and KRT19 were found (Gawantka, et al., 1998) in ventrally enriched transcripts. The transcription factor SP7 (also known as Osterix), a well-characterized target of Wnt signaling in Xenopus development (Kjolby and Harland, 2016; Nakamura et al., 2016) was also increased. Xenbase.com provides a rich resource for in situ expression pattern of $S P 7$ (the neural ridge at neurula), and for that of many of the other genes identified in these genome-wide analyses.

The results at late gastrula are shown in the heatmap of Fig. 2 and in Table 2. Embryos were cut at midblastula and allowed to regenerate for about 9 hours at stage 12. In one of the three experiments, one of the sagittal halves was ventralized and the other dorsalized, indicating that in this particular embryo the bisection missed the sagittal plane (experiment 2 in Table S2). The other two experiments showed no $\mathrm{D}-\mathrm{V}$ preference, indicating that the midline was properly bisected (experiments 1 and 3 in Table S2). A total of 25 genes were up-regulated preferentially in regenerating sagittally cut twins.

Interestingly, when ranked according to RPKM levels, the top gene increased by sagittal bisection was SOX2 (Table S2), a gene essential for the pluripotent and self-renewing properties of embryonic stem cells (Takahashi and Yamanaka, 2006), and an early dorsal gastrula and later a neural plate marker in Xenopus (see Xenbase and De Robertis et al., 1997). The next gene was EOMES, a T-box transcription factor crucial for endomesodermal differentiation in Xenopus and mouse (Ryan et al., 1996; Russ et al., 2000) expressed strongly in dorsal mesoderm and more weakly in ventral mesoderm at gastrula (see Xenbase). The transcription of eomesodermin is regulated by Sox2, which together with Oct4 and Nanog binds to the core regulatory circuitry in human embryonic stem cells (Boyer et al., 2011; Teo et al., 2011). SERPINH1 transcripts were increased in sagittal sections of both experiments (Table 2). This is a protein required for the proper folding of the triple helix of Procollagen I, which when mutated causes osteogenesis imperfecta (Ito and Nagata, 2017). Two other genes, RIPPLY2, and FUCOLECTIN were up-regulated in two alloalleles in regenerating twins but within the same experiment (Table 2). Xenopus laevis is an allotetraploid species and many genes are present in two copies in Long or Short chromosomes (Session et al., 2016). When mutated, RIPPLY2 causes vertebral segmentation defects in humans (Mclnerney-Leo et al., 2015). Interestingly, RIPPLY2 is a regulator of T-box proteins (the family to which Eomesodermin belongs), converting Tbx6, Tbx24 and Brachyury from activators to repressors. This is achieved by recruiting the transcriptional repressor Groucho 4 (Kawamura et al., 2008) and by recruiting Tbx6 to the proteasome for degradation (Zhao et al., 2018). Xenopus laevis ripply2 is expressed in presomitic mesoderm (according to Xenbase). FUCOLETIN (also known in Xenopus as epilectin) is a lectin that binds fucose and is induced by Bone Morphogenetic Proteins (BMP) in ventral ectoderm at stage 12 (Massé et al., 2004; Xenbase).

Other genes induced in sagittal regenerating embryos were found only once (Table 2). APOC1, encodes Apolipoprotein C1, a protein that binds to very low density lipoproteins in serum and has the interest of being a Wnt-induced gene required for neural crest formation (Yokota et al., 2017). FKBP9 is a peptidyl-prolyl cis-trans isomerase (Jo et al., 2001). ZNF451 is an epidermal gene 
TABLE 3

TRANSCRIPTS REPRESSED BY SAGITTAL BISECTION IN STAGE 10.5 EMBRYOS*

\begin{tabular}{|c|c|c|c|c|c|c|c|c|}
\hline JGI9 ID & Human ID & Con. & L. half & R. half & D. half & V. half & p-value & Exp. \# \\
\hline SzI.L & SFRP2 & 34.93 & 8.20 & 8.56 & 1.57 & 241.04 & 0.05 & 3 \\
\hline Xelaev18000342m & $\# N / A$ & 29.95 & 4.14 & 4.71 & 19.68 & 48.09 & 0.12 & 2 \\
\hline szl.S & SFRP2 & 24.83 & 5.88 & 9.32 & 1.55 & 141.34 & 0.18 & 3 \\
\hline Xelaev18000337m & ZCCHC3 & 16.09 & 3.84 & 3.87 & 24.34 & 51.12 & 0.03 & 1 \\
\hline Xelaev18040512m & DAPK2 & 13.96 & 6.50 & 6.90 & 6.33 & 26.00 & 0.06 & 3 \\
\hline Xelaev18000342m & $\# \mathrm{~N} / \mathrm{A}$ & 11.26 & 0.88 & 1.47 & 20.38 & 49.13 & 0.12 & 1 \\
\hline degs3.L & DEGS2 & 8.57 & 3.46 & 3.19 & 3.48 & 12.72 & 0.02 & 3 \\
\hline Xetrov90028501m.1 & $\# \mathrm{~N} / \mathrm{A}$ & 6.17 & 1.19 & 2.12 & 2.62 & 28.45 & 0.14 & 3 \\
\hline Xelaev18003951m & \#N/A & 5.37 & 0.00 & 0.62 & 1.19 & 20.26 & 0.15 & 1 \\
\hline Xelaev18010379m & TBX3 & 4.31 & 1.54 & 2.02 & 0.94 & 11.16 & 0.05 & 2 \\
\hline Xetrov90028501m.1 & \#N/A & 3.72 & 0.61 & 0.58 & 4.65 & 11.06 & 0.14 & 1 \\
\hline Xelaev18009910m & CRYGB & 3.44 & 0.41 & 0.82 & 1.51 & 5.63 & 0.07 & 3 \\
\hline Xelaev18034023m & $\# \mathrm{~N} / \mathrm{A}$ & 1.77 & 0.42 & 0.14 & 2.90 & 7.31 & 0.09 & 1 \\
\hline Xelaev18004073m & $\# \mathrm{~N} / \mathrm{A}$ & 15.03 & 1.19 & 0.00 & 21.40 & 7.09 & 0.05 & 3 \\
\hline Xelaev18019555m & PLSCR3 & 2.09 & 0.50 & 0.00 & 6.45 & 0.77 & 0.14 & 2 \\
\hline
\end{tabular}

*Listed according to average RPKM levels in control-embryos.

in Xenopus (Gawantka et al., 1998). ACVR1 is Activin A Receptor Type, a gene important for mesoderm induction (Asashima et al., 2008). CISD1 is an outer-mitochondrial membrane protein (Wiley et al., 2007). FAM220A and NR2C2AP are little-known proteins. COMT is chatechol-O-mehtyltransferase-like. EP300 is the wellknown histone acetyl-transferase transcriptional coactivator p300. SGPP1 is Sphingosine-1 phosphate phosphatase 1. MIEN1 is the secreted protein migration and invasion enhancer 1 involved in cancer metastases. GPR161 encodes a G protein-coupled 7 transmembrane receptor that has the interest of being important for Hedgehog signaling at the level of stereocilia (Hwang et al., 2018). ST3GAL4 is $b$-galactoside $\alpha$-2,3-sialyltransferase 4 , an enzyme that adds sialic acid to glycoproteins in the cell surface (HarduinLepers et al., 2001). Finally, TPX2 is a microtubule-associated spindle assembly factor.

Taken together, this whole-genome transcriptome data of genes up-regulated during twinning support a model in which cell division is required at early gastrula, while at late gastrula pluripotency and germ-layer specification genes show increased expression in identical twins.

\section{Transcripts down-regulated in twinning embryos}

Genes down-regulated by sagittal bisection were also analyzed. Table 3 displays 25 transcripts repressed in sagittally bisected embryos at stage 10.5 that were identified using very stringent conditions (two-fold repression in sagittal halves and over two-fold induction in ventral or dorsal fragments with respect to controls embryos) to eliminate wound response genes. When ranked according to difference between control and sagittal RPKM levels, the gene most repressed by sagittal bisection was Sizzled (Table 3), a competitive inhibitor of Xolloid proteinases and a major regulator of BMP signaling during gastrulation (Lee et al., 2006). Sizzled is an SFRP (secreted frizzled-related protein, most related to human SFRP2) expressed in the ventral side of the gastrula (see Xenbase) and fulfills a critical role in D-V patterning by acting as a competitive inhibitor of Chordin degradation (Plouhinec et al., 2013). Thus, when Sizzled levels are low, Chordin protein levels are expected to be high (De Robertis et al., 2017). Sizzled was also the only gene found twice, both in its Long and Short forms present in the Xenopus laevis allotetraploid species.

Thirteen other transcripts were also decreased in sagittal half-

TABLE 4

TRANSCRIPTS REPRESSED BY SAGITTAL BISECTION IN STAGE 12 EMBRYOS*

\begin{tabular}{|c|c|c|c|c|c|c|c|c|}
\hline JGI9 ID & Human ID & Con. & L. half & R. half & D. half & V. half & p-value & Exp. \# \\
\hline Xelaev18030475m & ZNF268 & 57.21 & 27.46 & 22.47 & 19.45 & 89.24 & 0.01 & 1 \\
\hline acaa2.S & ACAA2 & 37.49 & 16.73 & 13.90 & 17.14 & 80.33 & 0.08 & 1 \\
\hline Xelaev18040968m & ATP6V1A & 34.71 & 12.63 & 14.50 & 19.36 & 80.57 & 0.05 & 1 \\
\hline Xelaev18000342m & $\# \mathrm{~N} / \mathrm{A}$ & 32.77 & 7.11 & 15.06 & 18.18 & 88.12 & 0.00 & 3 \\
\hline foxj1.S & FOXJ1 & 19.67 & 9.11 & 5.72 & 7.68 & 36.08 & 0.03 & 1 \\
\hline foxi1.L & FOXI1 & 13.31 & 1.88 & 2.59 & 0.81 & 22.54 & 0.03 & 1 \\
\hline Xelaev18008287m & MCIDAS & 6.15 & 2.17 & 1.71 & 0.16 & 19.57 & 0.12 & 1 \\
\hline cebpd.L & CEBPD & 5.99 & 1.16 & 0.87 & 1.66 & 12.68 & 0.00 & 3 \\
\hline capn8.S & CAPN8 & 5.58 & 2.35 & 1.92 & 1.62 & 20.03 & 0.00 & 3 \\
\hline Xelaev18008287m & MCIDAS & 4.41 & 1.61 & 0.91 & 0.92 & 10.91 & 0.12 & 3 \\
\hline Xelaev18043178m & UBP1 & 4.06 & 1.48 & 0.50 & 0.64 & 13.20 & 0.28 & 3 \\
\hline
\end{tabular}

*Listed according to average RPKM levels in control-embryos. 


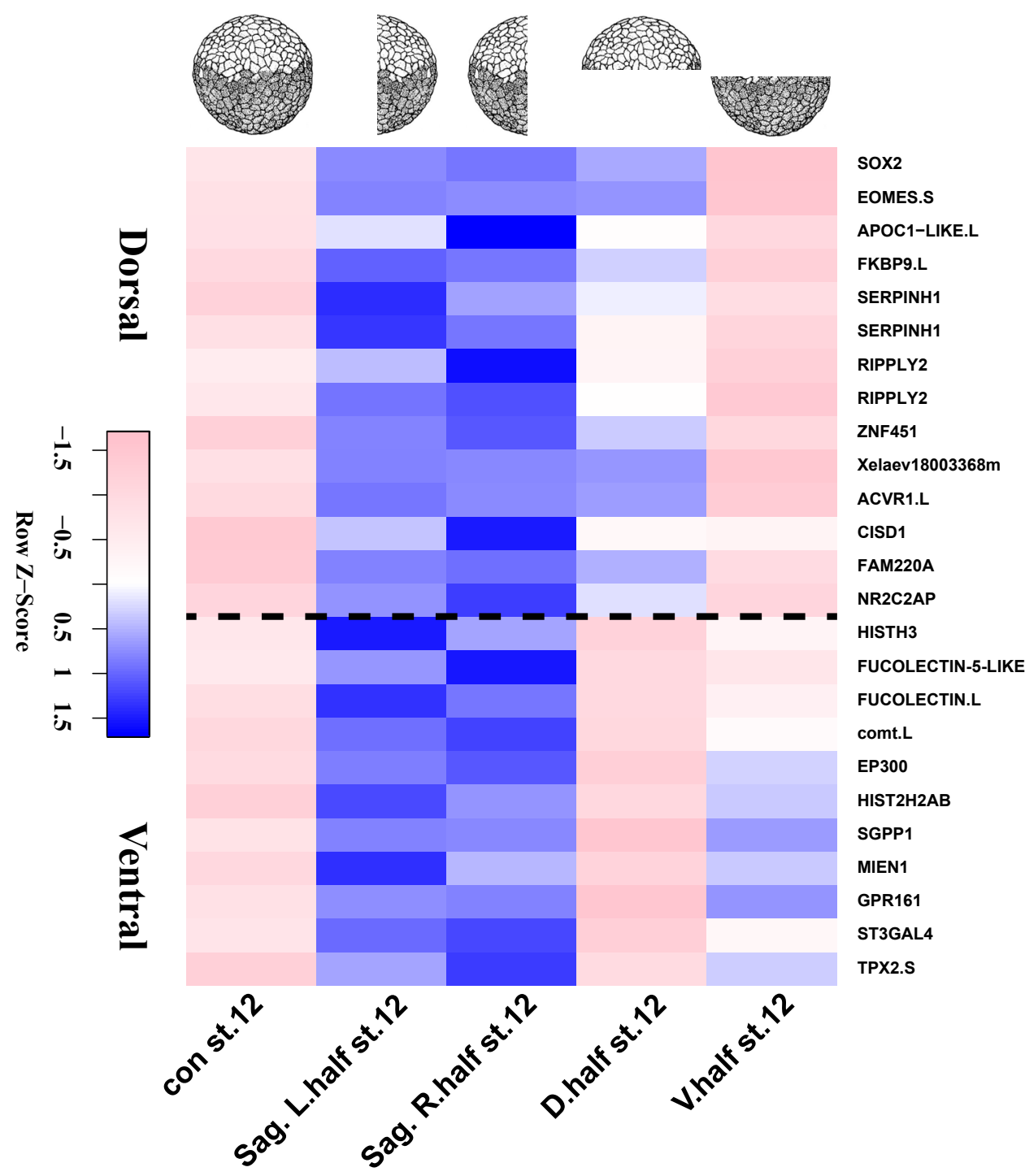

Fig. 2 Heatmap of genes up-regulated by sagittal bisection in regenerating stage 12 late gastrula Xenopus laevis embryos. Heatmap showing the horizontal Row Z-scores of genes bisected at stage 8 and cultured until stage 12. Standard deviations were calculated from RPKMs of transcripts in left, right, and dorsal/ventral halves (see also Table 2). Highly expressed genes are shown in blue and lower ones in pink.

embryo fragments at stage 10.5, mostly among ventrally-expressed genes. Many of them were novel genes. Among the identified genes, DAPK2 is a positive regulator of programmed cell death (Yuasa, et al., 2015). DEGS2 plays a pivotal role in phytosphingolipid biosynthesis in skin and differentiation of human keratinocytes (Mizutani et al., 2004). TBX3, is a T-box transcription factor crucial for mesendodermal differentiation in Xenopus (Weidgang, et al., 2013). TBX3 inhibits BMP4 to regulate retina patterning (Motahari, et al., 2016) and mutations of TBX3 have been found to cause dominant autosomal ulnar-mammary syndrome (He et al., 1999). CRYGB (crystallin gamma $B$ ) is a protein expressed in the early hindbrain and required for lens regeneration and development (Day and Beck, 2011). Finally, PLSCR3 is a regulator of mitochondrial structure and respiration. (Liu et al., 2003).

Table 4 shows genes decreased in both sides of individual sagittal half-embryos. They were all ventrally enriched transcripts, and found only in one embryo. Of the 11 genes, one lacked human homologues. ZNF268 is a zinc finger protein involved in human liver development (Sun et al., 2004). ACAA2 is a liver enzyme in the fatty acid oxidation pathway (Sodhi et al., 2014). Two other genes, CEBPD and UBP1, also regulate lipid metabolism (Lai et al., 2017; Koutnikova et al., 2009). ATP6V1A is a subunit of V-ATPase (Jing et al., 2019). MCIDAS regulates cell cycle progression (Pefani et al., 2011) and FOXI1 cell proliferation (Dou et al., 1999). Calpain8 regulates cranial neural crest cell migration (Cousin et al., 2010). HoxJ1 is transcription factor specifically required for the formation of motile cilia. Interestingly, HoxJ1 is down-regulated by Nanog (Siu et al., 2013). Since HoxJ1 is down-regulated by sagittal section, this observation might be in line with the view that pluripotency may be sustained during self-regeneration.

The genome-wide analysis of transcripts decreased during twinning indicated that ventral genes involved in Chordin degradation, cell proliferation and lipid metabolism were down-regulated.

\section{Discussion}

The mechanism by which embryos self-organize to regenerate pattern has fascinated embryologists since the beginnings of experimental embryology (Driesch, 1891; Morgan, 1895; Spemann, 1938). In a recent study we reported that in bisected Xenopus embryos the Spemann organizer is formed $90^{\circ}$ away from its usual location (Moriyama and De Robertis, 2018). In that study, we were unable to identify any transcripts up-regulated specifically in sagittal bisections (when compared to D-V half-embryos in which wound healing genes are also activated) by analyzing groups of six pooled embryos. We now present the analysis of individualembryonic halves. Deep transcriptome analyses were possible due to the large size of the Xenopus embryo. The RNA-seq data from the 30 individual libraries bisected at midblastula and allowed to regenerate until gastrula stages 10.5 or 12 (available in supplemental tables S1 and S2 in a searchable Excel format, or as raw data at Gene Expression Omnibus database of the $\mathrm{NIH}$, number GSE124563), provide a very rich resource to mine for genes regulated in the early vertebrate embryo. For example, all of the known Spemann organizer and ventral center genes (Reversade and De Robertis, 2005; De Robertis et al., 2017), as well as others previously unknown, are strongly represented in the dorsal and ventral half-embryos bisected at stage 8 and allowed 
to regenerate until stage 12 (data available in Supplemental Table S2). Genes expressed on the dorsal fragment will include those responsible for the phenomenon known as scaling, by which a well-proportioned embryo of half the size is formed from the dorsal half embryo (Plouhinec et al., 2013).

One main conclusion that emerged is from the analysis of upregulated genes was that genes of the $D-V$ morphogenetic pathway were not specifically overexpressed in regenerating twin embryos. This indicates that the displacement of the site of Spemann organizer formation may be achieved by non-transcriptional mechanisms during self-organization (Moriyama and De Robertis, 2018). In other words, our analysis did not reveal obvious master control genes up-regulated during regeneration at a transcriptional level. Diffusible molecules such as BMPs and Wnts may be sufficient to displace formation of the dorsal organizer, which self-regulates without large changes in the maximal expression levels of $D-V$ genes (Fig. 1). However, the strong decrease in levels of sizzled expression during twinning suggests that Chordin protein levels might be increased indirectly, though the competitive inhibition of the Tolloid enzymes that degrade Chordin (Lee et al., 2006; De Robertis et al., 2017).

A drawback of our analysis is that we applied very stringent criteria to identify genes expressed differentially in sagittal versus $D-V$ half embryos, to circumvent the activation of wound-healing genes. At early gastrula ( 4.5 hours after bisection) increased transcripts were mostly histones, presumably indicating a higher cell proliferation rate. Notably, at late gastrula (9 hours after bisection) several genes involved in stem cell pluripotency and germ layer determination (Sox2, Eomesodermin, Ripply 2, and ACVR1) were up-regulated specifically in sagittal twins (Fig. 2, Table2).

Importantly, the data presented here in Supplemental Tables S1 and S2 contains all transcriptome changes taking place at stages 10.5 and 12, and can be mined for many more additional interesting transcripts specifically up-regulated or down-regulated in experimentally twinned embryos simply by allowing for less stringent levels of differential expression. The data presented here represents a rich resource for the transcriptional changes that underlie twinning. The data for individual Dorsal and Ventral half embryos bisected at midblastula and allowed to regenerate until late gastrula offer the most exhaustive repertoire of $D-V$ regulated genes available for a vertebrate embryo (supplemental Table S2).

\section{Materials and Methods}

\section{Embryo manipulation and generation of sagittal half embryos}

Xenopus laevis frogs were purchased from Nasco and all procedures were as approved by the animal research committee of the University of California, Los Angeles. Embryos were fertilized with sperm suspension (Sive et al., 2000). Embryos with the best D-V polarity (Klein, 1987) were selected at the 2- and 4-cell stages, cultured in $0.1 \times$ Marc's modified Ringer's and staged (Nieuwkoop and Faber, 1967). Stage 8 embryos were manually dechorionated with watchmaker forceps and bisected with an eyelash knife in $0.3 \times$ Modified Barth's Solution (MBS, Gurdon, 1976) as described by Moriyama and De Robertis (2018). Sagittal bisections cut the dorsal crescent in half, while dorsal and ventral halves were sectioned perpendicular to that plane. Half embryos were rinsed to remove dead cells with a glass pipette and transferred within 3 min into depressions made in $2 \%$ agar-coated plates and allowed to heal for $60 \mathrm{~min}$ in $0.3 \times \mathrm{MBS}$ solution with the large wound facing upwards. Next, sibling half embryos were placed in fresh depressions in separate agar coated plates and cultured in $0.1 \times$ MBS until they reached stage 10.5 or 12 (Nieuwkoop and Faber,
1967). The frequency of well-patterned twins was increased by choosing those embryos in which the large wound left by bisection was completed within 60 minutes, followed by a second screening for those sagittal half embryos in which the dorsal lip formed $90^{\circ}$ away from the healing point. For stage 12 sagittally bisected embryos, a further selection was performed choosing half-embryos with asymmetric pigmentation on the left and right sides (see Moriyama and De Robertis, 2018).

\section{RNA sequencing and data analysis}

Total RNA was isolated from single whole or half embryos using the Absolutely RNA Miniprep Kit (Agilent). 500 ng of RNA were used to construct each library, using the Illumina TruSeq RNA Library Preparation Kit V2 following the manufacturer's protocol. Each library was sequenced in an Illumina Hi-SEq 2000 to generate 100-bp single-end reads at the Broad Stem Cell Research Center at the University of California, Los Angeles (UCLA). RNA sequencing data were processed as described previously (Anders and Huber, 2010; Love et al., 2014; Ding et al., 2017b). Reads were mapped against protein-coding regions in the JGI9.1 (XENLAv9.1) version of the Xenopus laevis genome (Session et al., 2016) which is available at Xenbase. Human gene names (Tables S1 and S2) were assigned by blasting JGI9.1 peptide sequences to human reference protein sequences, as described previously (Ding et al., 2017b). The RNA-seq data are publicly available at the N.I.H. Gene Expression Omnibus (GEO), accession no. GSE124563.

\section{Heatmap}

The heatmap in Fig. 2 was generated in R-Studio using RPKM of the indicated genes as input. Horizontal Row Z-scores were obtained from the RPKMs by calculating the mean, variance, and standard deviation of each transcript by using the gplots v3.0.1 package available from R-Studio. The rows/genes and columns/conditions were left unclustered.

\section{Acknowledgements}

Y.M., Y.D., G.C. were supported by HHMI, E.A.S. was supported by a MARC undergraduate fellowship (NIH T34 GM-008563) and N.T.M. by a University of California Institute for Mexico and the United States (UC Mexus) and the Consejo Nacional de Ciencia y Tecnologia (CONACYT) postdoctoral fellowship (FE-17-65). This work was supported by Norman Sprague Endowment and the Howard Hughes Medical Institute, of which E.M.D.R. is an Investigator.

All RNA-seq data is available at GEO, accession number GSE124563.

\section{References}

ANDERS, S. and HUBER, W. (2010). Differential expression analysis for sequence count data. Genome Biol 10: R106.

ASASHIMA, M., MICHIUE, T. and KURISAKI, A. (2008). Elucidation of the role of activin in organogenesis using a multiple organ induction system with amphibian and mouse undifferentiated cells in vitro. Dev Growth Differ 50: S35-45.

BERTOCCHINI, F. and STERN, C.D. (2002). The hypoblast of the chick embryo positions the primitive streak by antagonizing nodal signaling. Dev Cell 5: 735-744.

BOYER, L.A., LEE, T.I., COLE, M.F., JOHNSTONE, S.E., LEVINE, S.S., ZUCKER, J.P., GUENTHER, M.G., KUMAR, R.M., MURRAY, H.L., JENNER, R.G., GIFFORD, D.K., MELTON, D.A., JAENISCH, R. and YOUNG R.A. (2005). Core transcriptional regulatory circuitry in human embryonic stem cells. Cell 122: 947-956.

BRIGGS, J.A., WEINREB, C., WAGNER, D.E., MEGASON, S., PESHKIN, L., KIRSCHNER, M.W. and KLEIN, A.M. (2018). The dynamics of gene expression in vertebrate embryogenesis at single-cell resolution. Science 360: eaar5780.

CARTER, A.M. (2018). Classics revisited: Miguel Fernández on germ layer inversion and specific polyembryony in armadillos. Placenta 61: 55-60.

COUSIN, H., ABBRUZZESE, G., KERDAVID, E., GAULTIER, A. and ALFANFARI D. (2010). Translocation of the Cytoplasmic Domain of ADAM13 to the Nucleus Is Essential for Calpain8-a Expression and Cranial Neural Crest Cell Migration. Dev Cell 20: 256-263.

DAY, R.C. and BECK, C.W. (2011). Transdifferentiation from cornea to lens in Xenopus 
laevis depends on BMP signalling and involves upregulation of Wnt signaling. BMC Dev Biol 11: 54.

DE ROBERTIS, E.M. (2006). Spemann's organizer and self-regulation in amphibian embryos. Nat Rev Mol Cell Biol 4: 296-302.

DE ROBERTIS, E.M., KIM, S., LEYNS, L., PICCOLO, S., BACHILLER, D., AGIUS, E., BELO, J.A., YAMAMOTO, A., HAINSKI-BROUSSEAU, A., BRIZUELA, B. WESSELY, O., LU, B. and BOUWMEESTER T. (1997). Patterning by genes expressed in Spemann's organizer. Cold Spring Harb Symp QuantBiol. 62: 169-175.

DE ROBERTIS, E.M., MORIYAMA, Y. and COLOZZA, G. (2017). Generation of animal form by the Chordin/Tolloid/BMP gradient: 100 years after D'Arcy Thompson. Dev Growth Differ 59: 580-592.

DING, Y., COLOZZA, G., SOSA, E.A., MORIYAMA, Y., RUNDLE, S., SALWINSKI, L. and DE ROBERTIS, E.M. (2018). Bighead is a Wnt antagonist secreted by the Xenopus Spemann organizer that promotes Lrp6 endocytosis. Proc Natl Acad Sci USA 115: E9135-E9144

DING, Y., COLOZZA, G., ZHANG, K., MORIYAMA, Y., PLOPER, D., SOSA, E.A., BENITEZ, M.D.J. and DE ROBERTIS, E.M. (2017b). Genome-wide analysis of dorsal and ventral transcriptomes of the Xenopus laevis gastrula. Dev Biol 426: 176-187.

DING, Y., PLOPER, D., SOSA, E.A., COLOZZA, G., MORIYAMA, Y., BENITEZ, M.D.J., ZHANG, K., MERKURJEV, D. and DE ROBERTIS, E.M. (2017a). Spemann organizer transcriptome induction by early beta-catenin, Wnt, Nodal, and Siamois signals in Xenopus laevis. Proc Natl Acad Sci USA 114: E3081-E3090.

DOU, C.L., LI, S. and LAI, E. (1999). Dual role of brain factor-1 in regulating growth and patterning of the cerebral hemispheres. Cereb Cortex 9: 543-550.

DRIESCH, H. (1891). Entwicklungsmechanische Studien: I. Der Werthe der beiden ersten Furchungszellen in der Echinogdermenentwicklung. Experimentelle Erzeugung von Theilund Doppelbildungen. Ztschr $f$ wiss Zoologie 53: 160-184.

GAWANTKA, V., POLLET, N., DELIUS, H., VINGRON, M., PFISTER, R., NITSCH, R., BLUMENSTOCK, C. and NIEHRS, C. (1998). Gene expression screening in Xenopus identifies molecular pathways, predicts gene function and provides a global view of embryonic patterning. Mech Dev 77: 95-141.

GURDON, J.B. (1976). Injected nuclei in frog oocytes: fate, enlargement, and chromatin dispersal. J Embryol Morphol 36: 523-540.

HALL, J.G. (2003). Twinning. Lancet, 362: 735-743.

HARDUIN-LEPERS, A., VALLEJO-RUIZ, V., KRZEWINSKI-RECCHI, M.A., SAMYNPETIT, B., JULIEN, S. and DELANNOY, P. (2001). The human sialyltransferase family. Biochimie 83: 727-737

HE, M.L., WEN, L., CAMPBELL, C.E., WU, J.Y. and RAO, Y. (1999). Transcription repression by Xenopus ET and its human ortholog TBX3, a gene involved in ulnar-mammary syndrome. Proc Natl Acad Sci USA 96: 10212-10217.

HWANG, S.H., WHITE, K.A., SOMATILAKA, B.N., SHELTON, J.M., RICHARDSON, J.A. and MUKHOPADHYAY, S. (2018). The G protein-coupled receptor Gpr161 regulates forelimb formation, limb patterning and skeletal morphogenesis in a primary cilium-dependent manner. Development 145: dev154054.

ITO, S. and NAGATA, K. (2017). Biology of Hsp47 (Serpin H1), a collagen-specific molecular chaperone. Semin Cell Dev Biol 62: 142-151.

JING, F., GENG, Y., XU, X.Y., SHI, J.S. and XU, Z.H (2019). MicroRNA29a Reverts the Activated Hepatic Stellate Cells in the Regression of Hepatic Fibrosis through Regulation of ATPase $\mathrm{H}^{+}$Transporting V1 Subunit C1. Int J Mol Sci 20: E796.

JO, D., LYU, M.S., CHO, E.G., PARK, D., KOZAK, C.A. and KIM, M.G. (2001). Identification and genetic mapping of the mouse Fkbp9 gene encoding a new member of FK506-binding protein family. Mol Cells 12: 272-275.

KAWAMURA, A., KOSHIDA, S. andTAKADA, S. (2008). Activator-to-repressor conversion of T-box transcription factors by the Ripply family of Groucho/TLE-associated mediators. Mol Cell Biol 28: 3236-3244.

KIRSCH, N., CHANG, L.S., KOCH, S., GLINKA, A., DOLDE, C., COLOZZA, G., BENITEZ, M.D.J., DE ROBERTIS, E.M. and NIEHRS, C. (2017) Angiopoietin-like 4 is a Wnt signaling antagonist that promotes LRP6 turnover. Dev Cell 43: 71-82.

KJOLBY, R.A. and HARLAND, R.M. (2016). Genome-wide identification of Wnt/ $\beta$ catenin transcriptional targets during Xenopus gastrulation. DevBio/426: 165-175.

KLEIN, S.L. (1987) The first cleavage furrow demarcates the dorsal-ventral axis in Xenopus embryos. Dev Biol 120: 299-304.

KOUTNIKOVA, H., LAAKSO, M., LU, L., COMBE, R., PAANANEN, J., KUULASMAA, T., KUUSISTO, J., HARING, H.U., HANSEN, T., PEDERSEN, O., SMITH, U.,
HANEFELD M., WILLIAMS, R.W. and AUWERX J. (2009). Identification of the UBP1 locus as a critical blood pressure determinant using a combination of mouse and human genetics. PLoS Genet 5: e1000591.

KRAUSE, G. and SANDER, K. (1962). Ooplasmic reaction system in insect embryogenesis. Adv Morphog 2: 259-303.

LAI, H.Y., HSU, L.W., TSAI, H.H., LO, Y.C., YANG, S.H., LIU, P.Y. and WANG, J.M. (2017). CCAAT/enhancer-binding protein delta promotes intracellular lipid accumulation in M1 macrophages of vascular lesions. Cardiovasc Res 113: 1376-1388.

LEE, H.X., AMBROSIO, A.L., REVERSADE, B. and DE ROBERTIS, E.M. (2006) Embryonic Dorsal-Ventral Signaling: Secreted Frizzled-Related Proteins as Inhibitors of Tolloid Proteinases. Cell 124: 147-159.

LIU, J., DAI, Q., CHEN, J., DURRANT, D., FREEMAN, A., LIU, T., GROSSMAN, D. LEE, R.M. (2003). Phospholipid scramblase 3 controls mitochondrial structure, function, and apoptotic response. Mol Cancer Res 1: 892-902.

LOVE, M.I., HUBER, W. and ANDERS, S. (2014). Moderated estimation of fold change and dispersion for RNA-seq data with DESeq2. Genome Biol 12: 550.

MARTYN, I., KANNO, T.Y., RUZO, A., SIGGIA, E.D. and BRIVANLOU, A.H. (2018) Self-organization of a human organizer by combined Wnt and Nodal signalling. Nature 558: 132-135.

MASSÉ, K., BALDWIN, R., BARNETT, M.W. and JONES, E.A. (2004). X-epilectin: a novel epidermal fucolectin regulated by BMP signalling. Int J Dev Biol48: 1119-1129.

MCINERNEY-LEO, A.M., SPARROW, D.B., HARRIS, J.E., GARDINER, B.B. MARSHALL, M.S., O'REILLY, V.C., SHI, H., BROWN, M.A., LEO, P.J., ZANKL, A., DUNWOODIE, S.L. and DUNCAN, E.L. (2015). Compound heterozygous mutations in RIPPLY2 associated with vertebral segmentation defects. Hum Mol Genet 24: 1234-1242.

MIZUTANI, Y., KIHARA, A. and IGARASHI, Y. (2004). Identification of the human sphingolipid C4-hydroxylase, hDES2, and its up-regulation during keratinocyte differentiation. FEBS Lett. 563: 93-97.

MORGAN, T.H. (1895). Half embryos and whole embryos from one of the first two blastomeres. Anat. Anz. 10: 623-638.

MORIYAMA, Y. and DE ROBERTIS, E.M. (2018). Embryonic regeneration by relocalization of the Spemann organizer during twinning in Xenopus. Proc Natl Acad Sci USA 115: E4815-E4822.

MOTAHARI, Z., MARTINEZ-DE LUNA, R.I., VICZIAN, A.S. and ZUBER, M.E. (2016) Tbx3 represses bmp4 expression and, with Pax6, is required and sufficient for retina formation. Development 143: 3560-3572

NAKAMURA, Y., DE PAIVAALVES, E., VEENSTRA, G.J.C. and HOPPLER, S. (2016) Tissue- and stage-specific Wnt target gene expression is controlled subsequent to $\beta$-catenin recruitment to cis-regulatory modules. Development 143: 1914-1925.

NIEUWKOOP, P.D. and FABER, J. (1967). Normal Table of Xenopus laevis (Daudin): A Systematical and Chronological Survey of the Development from the Fertilized Egg till the End of Metamorphosis (Garland Publishing Inc., New York) (republished in 1994).

PEFANI, D.E., DIMAKI, M., SPELLA, M., KARANTZELIS, N., MITSIKI, E., KYROUSI, C., SYMEONIDOU, I.E., PERRAKIS, A., TARAVIRAS, S. and LYGEROU, Z. (2011). Idas, a novel phylogenetically conserved geminin-related protein, binds to geminin and is required for cell cycle progression. J Biol Chem 286: 23234-23246.

PLOUHINEC, J.L., ZAKIN, L., MORIYAMA, Y. and DE ROBERTIS, E.M. (2013). Chordin forms a self-organizing morphogen gradient in the extracellular space between ectoderm and mesoderm in the Xenopus embryo. Proc Natl Acad Sci USA 110: 20372-20379.

REVERSADE, B. and DE ROBERTIS, E.M. (2005). Regulation of ADMP and BMP2/4/7 at opposite embryonic poles generates a self-regulating morphogenetic field Cell 123: 1147-1160.

RUSS, A.P., WATTLER, S., COLLEDGE, W.H., APARICIO, S.A., CARLTON, M.B., PEARCE, J.J., BARTON, S.C., SURANI, M.A., RYAN, K., NEHLS, M.C., WILSON V. and EVANS, M.J. (2000). Eomesodermin is required for mouse trophoblast development and mesoderm formation. Nature 404: 95-99.

RYAN, K., GARRETT, N., MITCHELL, A. and GURDON, J.B. (1996). Eomesodermin a key early gene in Xenopus mesoderm differentiation. Cell 87: 989-1000.

SASAI, Y. (2013). Cytosystems dynamics in self-organization of tissue architecture. Nature 493: 318-326.

SESSION, A., UNO, Y., KWON, T., CHAPMAN, J., TOYODA, A., TAKAHASHI, S., FUKUI, A., HIKOSAKA, A., PUTNAM, N., STITES, J., VAN HEERINGEN, S. 
QUIGLEY, I., HEINZ, S., HELLSTEN, U., LYONS, J.B., SUZUKI, A., KONDO, M., OGINO, H., OCHI, H., BOGDANOVIC, O., LISTER, R., GEORGIOU, G., PARANJPE, S.S., VAN KRUIJSBERGEN, I., MOZAFFARI, S., SHU, S., SCHMUTZ, J., JENKINS, J., GRIMWOOD, J., CARLSON, J., MITROS, T., SIMAKOV, O., HEALD, R., MILLER, K., HAUDENSCHILD, C., KUROKI, Y., TANAKA, T., MICHIUE, T., WATANABE, M., KINOSHITA, T., OHTA, Y., MAWARIBUCHI, S., SUZUKI, Y., HARAMOTO, Y., YAMAMOTO, T.S., TAKAGI, C., KITZMAN, J., SHENDURE, J., NAKAYAMA, T., IZUTSU, Y., ROBERT, J., DICHMANN, D., FLAJNIK, M., HOUSTON, D.W., MARCOTTE, E., WALLINGFORD, J., ITO, Y., ASASHIMA, M., UENO, N., MATSUDA, Y., VEENSTRA, G., FUJIYAMA, A., HARLAND, R.M., TAIRA, M. and ROKHSAR, D. (2016). Genome evolution in the allotetraploid frog Xenopus laevis. Nature 538: 336-343.

SIU, M.K., WONG, E.S., KONG, D.S., CHAN, H.Y., JIANG, L., WONG, O.G., LAM, E.W., CHAN, K.K., NGAN,H.Y., LE, X.F. and CHEUNG, A.N. (2013). Stem cell transcription factor NANOG controls cell migration and invasion via dysregulation of E-cadherin and FoxJ1 and contributes to adverse clinical outcome in ovarian cancers. Oncogene 32: 3500-3509.

SIVE, H.L., GRAINGER, R.M. and HARLAND, R.M. (2000). Early Development of Xenopus laevis: a Laboratory Manua (Cold Spring Harbor Laboratory Press, New York).

SODHI, S.S., GHOSH, M. and SONG, K.D. (2014). Acetyl CoA acyltransferase 2 ( $A C A A 2)$ is a key enzyme of fatty acid oxidation steps, which catalyzes the oxidation of fatty acid and plays an important role in the fatty acid metabolism. PLoS One 9: e102432.

SOZEN, B., AMADEI, G., COX, A., WANG, R., NA, E., CZUKIEWSKA, S., CHAPPELL, L., VOET, T., MICHEL, G., JING, N., GLOVER, D.M. and ZERNICKA-GOETZ, M. (2018). Self-assembly of embryonic and two extra-embryonic stem cell types into gastrulating embryo-like structures. Nat Cell Biol 20: 979-989.

SPEMANN, H. (1901). Entwickelungsphysiologische Studien am Triton-Ei. Arch $f$ Entw Mech Org 12: 224-264.

SPEMANN, H. (1938). Embryonic Development and Induction (Yale Univ. Press, New Haven).

SPRATT, N.T. and HAAS, H. (1960). Integrative mechanisms in development of the early chick blastoderm. I. Regulative potentiality of separated parts. J Exp Zool 145: 97-137.

SUN, Y., SHAO, H., LIU, J., GAO, L., PENG, X., MENG, Y. and LI, W. (2004). ZNF268, a novel kruppel-like zinc finger protein, is implicated in early human liver development. Int J Mol Med 14: 971-975.

TAKAHASHI, K. AND YAMANAKA, S. (2006). Induction of pluripotent stem cells from mouse embryonic and adult fibroblast cultures by defined factors. Cell126:663-676.

TEO, A.K., ARNOLD, S.J., TROTTER, M.W., BROWN, S., ANG, L.T., CHNG, Z., ROBERTSON, E.J., DUNN, N.R. and VALLIER, L. (2011). Pluripotency factors regulate definitive endoderm specification through eomesodermin. Genes Dev 25: $238-250$

WARMFLASH, A., SORRE, B., ETOC, F., SIGGIA, E.D. and BRIVANLOU, A.H. (2014). A method to recapitulate early embryonic spatial patterning in human embryonic stem cells. Nat Methods 8: 847-854.

WEIDGANG, C.E., RUSSELL, R., TATA, P.R., KÜHL, S.J., ILLING, A., MÜLLER M., LIN, Q., BRUNNER, C., BOECKERS, T.M., BAUER, K., KARTIKASARI, A.E., GUO, Y., RADENZ, M., BERNEMANN, C., WEI $\beta$, M., SEUFFERLEIN, T., ZENKE, M., IACOVINO, M., KYBA, M., SCHÖLER, H.R., KÜHL, M., LIEBAU, S. and KLEGER, A. (2013). TBX3 Directs Cell-Fate Decision toward Mesendoderm. Stem Cell Reports 1: 248-265.

WILEY, S.E., MURPHY, A.N., ROSS, S.A., VAN DER GEER, P. and DIXON, J.E. (2007). MitoNEET is an iron-containing outer mitochondrial membrane protein that regulates oxidative capacity. Proc Natl Acad Sci USA 104: 5318-5323.

YOKOTA, C., ÅSTRAND, C., TAKAHASHI, S., HAGEY, D.W. and STENMAN, J.M. (2017). Apolipoprotein C-I mediates Wnt/Ctnnb1 signaling during neural border formation and is required for neural crest development. Int J Dev Biol61:415-425.

YUASA, K., OTA, R., MATSUDA, S., ISSHIKI, K., INOUE, M. and TSUJI, A. (2015) Suppression of death-associated protein kinase 2 by interaction with 14-3-3 proteins. Biochem Biophys Res Commun. 464: 70-75.

ZHAO, W., OGINUMA, M., AJIMA, R., KISO, M., OKUBO, A. and SAGA, Y. (2018). Ripply2 recruits proteasome complex for Tbx6 degradation to define segment border during murine somitogenesis. Elife 7 pii: e33068. 


\section{Further Related Reading, published previously in the Int. J. Dev. Biol.}

Two modes of action by which Xenopus hairy2b establishes tissue demarcation in the Spemann-Mangold organizer Yasuhito Murato, Mami Yamaguti, Miho Katamura, Ken W.Y. Cho and Chikara Hashimoto

Int. J. Dev. Biol. (2006) 50: 463-471

https://doi.org/10.1387/ijdb.052106ym

From embryonic induction to cell lineages: revisiting old problems for modern study

Tokindo S. Okada

Int. J. Dev. Biol. (2004) 48: 739-742

http://www.intjdevbiol.com/web/paper/041918to

Activin-like signaling activates Notch signaling during mesodermal induction

Takanori Abe, Miho Furue, Yasufumi Myoishi, Tetsuji Okamoto, Akiko Kondow and Makoto Asashima Int. J. Dev. Biol. (2004) 48: 327-332

http://www.intjdevbiol.com/web/paper/041838ta

Siamois cooperates with TGFbeta signals to induce the complete function of the Spemann-Mangold organizer M J Engleka and D S Kessler

Int. J. Dev. Biol. (2001) 45: 241-250

http://www.intjdevbiol.com/web/paper/11291853

Organizer and axes formation as a self-organizing process

H Meinhardt

Int. J. Dev. Biol. (2001) 45: 177-188

http://www.intjdevbiol.com/web/paper/11291845

Amphibian embryos as a model system for organ engineering: in vitro induction and rescue of the heart anlage

H Grunz

Int. J. Dev. Biol. (1999) 43: 361-364

http://www.intjdevbiol.com/web/paper/10470654

Lens induction in axolotls: comparison with inductive signaling mechanisms in Xenopus laevis

M D Servetnick, T L Cook and R M Grainger

Int. J. Dev. Biol. (1996) 40: 755-761

http://www.intjdevbiol.com/web/paper/8877449
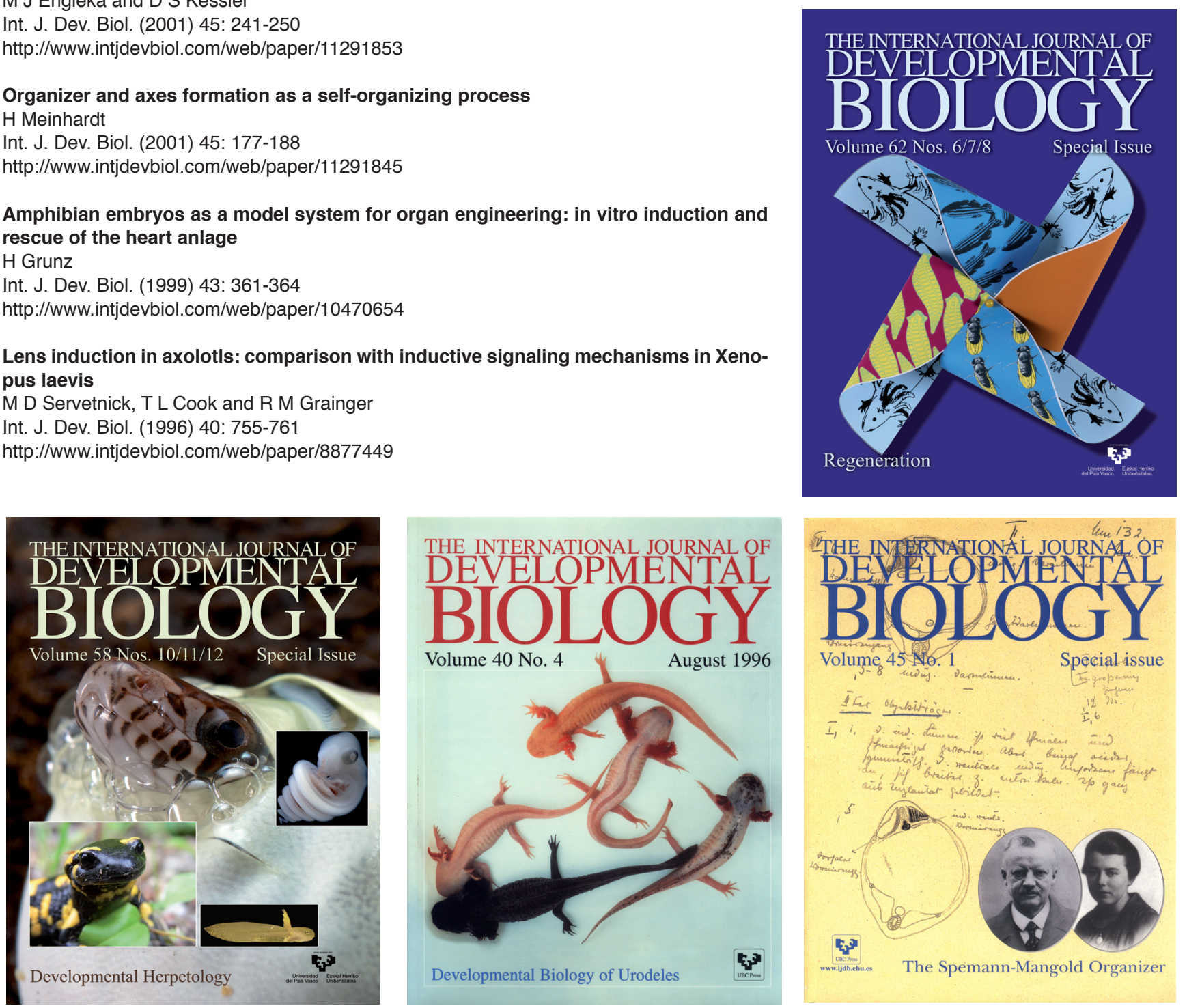